\title{
GCU
}

Glasgow Caledonian

University

University for the Common Good

\section{Impairment on the move: the disabled incomer and other invalidating intersections}

Hughes, Bill

Published in:

Disability and Society

DOI:

$10.1080 / 09687599.2017 .1298991$

Publication date:

2017

Document Version

Author accepted manuscript

Link to publication in ResearchOnline

Citation for published version (Harvard):

Hughes, B 2017, 'Impairment on the move: the disabled incomer and other invalidating intersections', Disability and Society, vol. 32, no. 4, pp. 467-482 . https://doi.org/10.1080/09687599.2017.1298991

\section{General rights}

Copyright and moral rights for the publications made accessible in the public portal are retained by the authors and/or other copyright owners and it is a condition of accessing publications that users recognise and abide by the legal requirements associated with these rights.

Take down policy

If you believe that this document breaches copyright please view our takedown policy at https://edshare.gcu.ac.uk/id/eprint/5179 for details of how to contact us. 


\section{Impairment on the move: The disabled incomer and other invalidating intersections}

\section{Introduction}

At the meeting point of disabled and migrant identities there is, on the part of many normate/host communities, a clearly articulated sensibility of closure and repatriation. Jennifer Harris (2003) described the experience of disabled asylum seekers in the UK in terms of the aphorism; 'all doors are closed to us'. At a global level, the number of closed doors multiplies significantly. The numbers on the move, traversing significant geographical distances, in order to resettle, is historically unprecedented (Castles and Miller 2003: Marfleet 2006). The World Health Organisation estimates that disabled people account for $7-10 \%$ of the world's population. This suggests that there are 4.4 to 6.2 million disabled people among the world's 65.3 million forcibly displaced persons (UNHCR 2016). It is not yet common practice, however, to 'include people with disabilities among those considered as particularly vulnerable in disasters and displacement and who, therefore, require targeted response' (Couldrey and Herson 2010: 2). Social amnesia about disability amongst the 'normate' community is common.

Globalisation has triggered extraordinary human mobility (Bauman 1998: Marfleet 2006) reshaping patterns of inclusion and exclusion (Gaventa and Tandon 2010). In this contemporary tale - unmatched in scale - of diasporas and uprooted lives, disabled migrants are 'the most invisible' (Boylan 1991). Usually, represented as a byword for immobility, disabled people, like millions of their non-disabled counterparts, are on the move. The struggle for citizenship and inclusion that has marked the social movement of disabled people in the $20^{\text {th }}$ and early $21^{\text {st }}$ centuries, has to be, for many millions, replayed anew in new polities where the rights of 'strangers', 'incomers, 'aliens' are anything but secure.

The question of citizenship sits uneasily alongside migrant status (Anderson 2015; Joppke 2010). The same is true of disabled people (Beckett 2006: Marks 1999). Even in the wealthy north they have been confined by disabling environments, hemmed in by inaccessible spaces, trapped by disabling barriers and placed 'out of 
sight' by prejudice, discrimination and exclusion (Swain et al 2014). Disabled people have had to struggle against obdurate and ubiquitous forms of invalidation for the dubious privilege of 'wage slavery', and for accessible environments that facilitate not only the right to work, but also the right to belong in communities of origin. To leave them behind and find new, welcoming communities, perhaps on the other side of the globe, is a significant challenge suggesting a lengthy battle against the immobilising environments of the contemporary world. The Disabled People's Movement (DPM) is engaged in intra-state battles to eliminate the spatial apartheid (Goggin and Newall 2005) that continues to segregate and exclude disabled people from the spaces that non-disabled people take for granted. Borders add a further dimension; a new layer of social relations, a tough testing ground for the politics of hospitality.

The disabled immigrant is in the very difficult position of making a claim to citizenship from a position of 'double(d) marginalization' and emotional resentment; consigned to the edge of social acceptability on two - largely autonomous - accounts. The incomer is a stranger - a source of fear, anxiety, hostility and disgust (Tyler 2013, Leudar et al 2008). The non-disabled response to disability invokes similar emotions (Hughes 2012; Soldatic and Meekosha 2012) including estrangement from nondisabled people who disavow and deny its applicability to their lives. It reminds them of the precariousness of being, the vulnerabilities of existence, of the worrying universal human tendency for people to break down and die (Shakespeare 1994, Hughes 2002). The perceived double threat - to community and to existential order, underwrites the likelihood that the disabled arrivant will experience a 'cumulative constellation of oppressions' (Harris 2003: 395). Disability is constituted as a figure that represents the existential stranger; the uninvited guest. It signifies the proximity of constitutional vulnerability. The immigrant, arriving uninvited from afar is depicted as bringing 'new ways' of doing and being that threaten the status quo. 'Persons with disabilities, located on the margins of society ... have historically taken on the coloration of whatever else is perceived to also lie on the margins of society' (Quayson 2007: 5). Indeed, the disabled figure and the figure of the migrant are, not only, mutually depicted by common location but are also lodestones that attract other nefarious 'scripts'. Disability as Ato Quayson (2007: 176) argues attracts 'stipulations of undesirability' that 'place, in close proximity, ideas of illness, 
deformity, insanity and criminality, sometimes interweaving the terms and leaving none of them entirely stable'. The migrant becomes the immigrant other; comes out of the margins as a pollutant (Cisneros 2008) an uninvited, undocumented, stranger who destabilises attachment to home and place. The incomer may be may be criminalised, racialised and made abject, if only by virtue of the geographical misadventure, of being 'here' but belonging 'there'. The immigrant as a carrier of disease and putative criminal are representations that have stood the test of time. The moral weight of terrorism is a burden of more recent origin. Both the disabled figure and the figure of the (im)migrant are magnets of pejorative representation.

In this paper, I discuss three distinct, historical examples of the reception afforded to the disabled incomer. I outline ways in which disabled people and migrants are blended by invalidating representations of character and indicate how these cultural 'scripts' (Molina 2014) combine to provide a social litmus test of the want of tolerance and hospitality. I also explore some of the intersections mobilised to develop and deepen the invalidating representations of disabled and migrating figures and note the frequent invocations of race in this context (Molina 2006). The historical examples come from the middle-ages, the $19^{\text {th }}$ century and contemporary neoliberalism. These snapshots in time indicate - genealogically - the play of ableist power in radically different historical contexts and trace how knowledge about impairment (on the move) is scripted by normate sensibilities that are premised on assumptions about the intractable difficulties that disabled people are expected to bring to the communities that they seek to enter

Crucial for migrant groups and groups like disabled and minority ethnic people for whom the margins have become home, is the deployment (or not) by the community, of an appropriate ethic of hospitality. Its absence has characterised the history of disability (Stiker 1999; Hughes 2015) and the intolerance that marks the lived experience of migrants seeking refuge or economic betterment in contemporary Europe is an instructive parallel. If one wishes to embrace the 'plural constituency of being and belonging' (Amin 2012: 3) offered by the multiple diasporas of the present, then one can learn from the experience of disabled people and migrants who have been conceived as social outliers; invalidated by communities who cannot see the stranger as a source of communion. Inhospitable communities may not recognise the fellow human in the wounded, wandering or ethnically different figure that seeks 
refuge in their midst. Disability - for non-disabled people in many historical circumstances - is the existential alien, par excellence - an unwelcome visitor with whom the 'wholesome self' would not wish to co-habit and commune. The case studies that follow illustrate this claim.

\section{The Christian middle-ages: inhospitable celestial borders}

There will be - in the view of the $4^{\text {th }}$ Century CE theologian St. Augustine and his teacher St Anslem - no 'monsters' or 'idiots' at the resurrection (Pender 1996; Metzler 2006). At the end of terrestrial time, the 'defective' and 'deformed' will be reembodied in 'the normal shape of man' (Stainton 2008: 490). This idea runs through the Patristic tradition in Christianity: 'Disabled Christians who did not benefit from miraculous cures while alive were promised the gift of able-bodiedness in the afterlife' (Wheatley 2010: 184). Though the process of carnal sanitisation is not outlined in any detail by the Church Fathers, the Bishop of Hippo is clear that, on the day of Judgement, somatic anomalies and mental 'deficiencies' will be washed away: 'And so all other births which have some excess or some defect or because of some conspicuous deformity, are called monsters will be brought again at the resurrection to the true form of human nature' (Augustine quoted in Brock 2012: 69).

Augustine posits a somatically appropriate way to appear before God. Disabled people may have been regarded as graciosi or 'recipients of God's special grace' (Cusack 1997: 417) but this applies only to His regard for them as vehicles for His miraculous works rather than as a 'special' case when it comes to the transmigration of souls across the celestial border.

Disability is a pivot of moral economy in the Christian middle-ages; particularly in its capacity as an object of charity and. It is therefore, a route for alms givers to clamber up the stairway to heaven. Disability offers significant spiritual 'use-value' in the salvation of privileged, non-disabled people. Yet, ironically, at the borders of heaven, disability is reduced to foul flesh and contamination; a blot on the landscape of perfection. Heaven, in the Christian theological imaginary is, for disabled people, an inhospitable territory policed by ableist border controls. The guards at the pearly gates operate an exclusion policy based on eugenic criteria. Medieval heaven operated a restrictive immigration policy. Entry depended on a decontamination 
programme in which bodily and mental impairment was washed away, leaving only the righteous matter commensurate with its pneuma. It seems that the exclusionary and hygienic practices associated with immigration policies in modernity (See the next two 'case studies') reprise celestial practices.

Normate groups can become trapped in a vacuum of homogeneity and tradition. They may be caught in 'the grip of the imaginary that each society exists as a homeland with its own people, known and loyal to itself and distinct from strangers from another land' (Amin 2012: 2). The Christian middle ages tried to make this myth of racial purity a reality for white Europe. It did so on the back of the perceived threat to Christendom from the Islamic east (Said 2003) and the perceived spiritual pollutants of heresy and sin that threatened the homeland from within (Moore 1987). These 'dark' figures - like their disabled counterparts - were represented by the forces of moral hegemony as out-groups. They too, were turned back by the border guards controlling entry to paradise. These strangers are - like their earthly counterparts - 'dirt', to use Mary Douglas' (1970) inspired euphemism for polluting and contaminating impact of 'matter out of place'. Strangers - for those who cannot bear the weight of otherness (Simmel 1971) - come from a different place, a place unknown and abject - be it geographical in the case of migrants or embodied in the case of disabled or minority ethnic people. Both places are spaces of impurity. The normate/host community may take the view that the threat of difference is too much to cope with; that the strangers should be cleared-out or cleaned-up; repatriated or integrated, exiled or dissolved into sameness. Strategically, therefore, the relationship between 'us' and 'them' is either 'anthropoemic' or 'anthropophagic' (Hughes 2002): The latter refers to normate practices of physical elimination or spatial exile; the former to the eradication of difference by radical assimilation (Bauman 1997). Celestial transformation of disabled migrants, 'miraculously', manages both simultaneously. The impairments of the terrestrial body are eliminated and replaced by a clean body that matches the purity of the soul. This process opens the door to heaven .

Whether or not eternal life was an embodied or disembodied experience and, if it was the former, what shape it would take, continued to vex thinkers - including John Locke - well into the enlightenment. Many envisaged the transformation of 
earthly flesh into substances that were angelic and ethereal and many agreed that the migration from mortality to immortality would involve the erasure of 'all that was imperfect and accidental' with 'the ethereal form highlighting youth, health and maturity' (Porter 2003: 103). Yet disabled bodies were not the only bodies that needed to be 'glorified' in order to pass muster in the afterlife. Theology in the age of colonialism had to deal with the transmigration and resurrection of native peoples:

'Taking then this blackness of the Negro to be an accidental imperfection ... we conclude thence, that he shall not rise with that complexion but leave it behind him in the darkness of the grave, exchanging it for a brighter and better complexion at his return again into the world (Quoted in Porter 2003: 104).

Like disabled people seeking entry into the kingdom of heaven, the earthly countenance of black people was considered improper. They may be rescued form their hapless state by a pneuma that can be stripped back to its white, able bodied essence. The Christian Heaven - at least in the past - has been comfortable as a proponent of racist and eugenic immigration policies. Modernity - as we will see below - follows suite.

\section{Eugenics: contamination of the stock by disabled migrants}

Ellis Island, today a museum in New York Bay, was an immigration processing station opened by the US Federal Government in 1891 in the wake of the Immigration Act of the same year. The act was designed to exclude the following categories of people from entering the USA. Insane and contagiously ill people, idiots, convicted felons, polygamists, paupers, and any person who might become a 'public charge on society'; 'Senility (old age), varicose veins, hernias, poor vision, and deformities of the limbs or spine were among the primary causes of exclusion' (Bateman-House and Fairchild 2008: 238). Concerned about the calibre and stock of people passing through Ellis Island, the State of New York had, prior to the federal take-over of immigration control, raised a statute to 'prevent the landing of mendicants, cripples, criminals, idiots \&c' (Schweik 2009: 165). 
The most striking feature of Ellis Island was the role it played in the protection of public health. This was based on eugenic fears of 'aliens' conceived as a contaminating threat to the physical and moral integrity of the nation. Ellis Island was primarily a site of medical inspection dedicated to the exclusion of 'degenerate' bodies, including people with impaired labour power (Fairchild 2003) who were thought to be unable to contribute to industrialisation and the prosperity of the nation (Dolmage 2011). These immigration priorities were supported - particularly after the introduction in the 1924 Immigration act of national quotas - by ethnic discrimination based on 'scientific racism' in which preferences for northern over eastern and southern Europeans were evident (Bateman-House and Fairchild 2008: 239). As Molina (2006) argues, US immigration policy has a long tradition of applying racialized representations to disabled immigrants and medicalised 'scripts' (Molina 2014) to non-white incomers. The same lexicon, highlighting the potential threat, embodied by both groups, is used to spell out and reiterate a dangerous intersection of corrupted flesh which the nation would do well to exclude from its shores. As we have seen, the policy is 'heaven-sent'.

The growing concern, in a land of immigrants, about the 'fitness' of incomers was a clear indication of the importance that eugenic conceptions of population - ableist and racist - acquired in nineteenth century America. Eugenics comes from the Greek word eugenes which means 'well born'. Eugenic policies are designed - as Plato recommended - to eliminate weakness and / or to help the 'well-born' to flourish. A restrictive immigration policy in late nineteenth century America was part of a wider strategy of bio-politics (Foucault 1979) that included eugenic approaches to health, hygiene and reproduction (Rose 2001). These policies were designed to manage the population and to contain and exclude 'undesirables'. They were designed to ensure, therefore, the vigour of the labour power of people and the sustainability of the nation. Blocking access to disabled people through the major points of entry into the USA was an important weapon of the state in the battle against 'degeneracy'. 'Degeneracy' was central to the rhetoric of late nineteenth/early twentieth century 'ideology of ablebodiedness' (Siebers 2008); a deeply embedded post-Darwinian fear which suggested that the moral decline of civilisation was evident in the mass of botched and broken bodies that drained prosperity from modern urban, industrialised, spaces (Pick 1989). 
Both the immigration act of 1891 and the New York statute are infused with semiotic potency. They combine representations of identities in ways that suggest nefarious intersections between on the one hand, impairment categories (cripples and idiots) and on the other criminals and mendicants. They condense crooked bodies and crooked behaviour into a singular physiognomic frame of reference. The 'folk devil' is all the more efficacious in the production of social anxiety when it is made from combinations of morally dubiety. By constructing a point of confluence at which migrant and disabled identities mix with the moral contaminants of miscreant and vagrant identities, the immigration regulations - much like the Ugly Laws that operated contemporaneously with them - aroused strong emotions of fear and disgust amongst the normate community (Schweik 2009). In successfully representing identities seeking to enter a body politic as constituting a potentially significant threat to the 'moral economy', it was relatively easy for legislators to point to the growing bands of unsightly, mutilated, urban mendicants, in order to legitimate a policy of deportation for those of similar embodied qualifications who presented themselves at the nation's borders as candidates for citizenship.

The connection between criminality and disability was a central proposition of the ableist imaginary of the day. It was evident in the populist 'pseudo-sciences' including, eugenics; physiognomy and the new 'scientific' criminology promulgated by Lombroso (1835-1909). These views suggested a causal connection between deformity and criminality and between racial type and crooked character. The practice of medical examiners and Public Health Service officials at Ellis Island was strongly influenced by these contemporary ideas and they used them to identify and 'isolate' potentially degenerate and undesirable immigrants who would then be recommended for deportation (Dolmage 2014). Writing in 1905, Dr Allan McLaughlin of the US Public Health and Marine Hospital Service notes, that he and his fellow officials at Ellis Island are practiced in the 'arts' of physiognomy: 'The gait and general appearance suggest health or disease to the practiced eye, and aliens who do not appear normal are turned aside'. They were wise also to the legendry deceitfulness of disability: 'The nonchalant individual with an overcoat on his arm is probably concealing an artificial arm; the child strapped to its mothers back, and who appears old enough to walk alone, may be unable to walk because of infantile 
paralysis' (McLaughlin 1905: no page number). The gaze is organised by pseudoscience to identify embodied signs of undesirability and to unmask its many disguises. Those not fit to contribute to the American dream are singled out and returned to their place of origin.

As Ato Quayson (2007: 176) has argued, representations of undesirability are fickle and eclectic, making brethren from a number of, more or less, nefarious moral characteristics including, 'illness, deformity, insanity and criminality'. Ethnicity is another marker of identity that is used to map an unstable 'interface with otherness' (Quayson 2007: 52) that helps the racialized and ableist framework to add virtue to the reputation of dominant cultural groups. At ports of entry to the USA, the deeply held eugenic sensibilities of the day were drummed into the Public Health Service officials (Bateman-House and Fairchild 2008). This helped them to identify 'degenerate identities' and the intersecting scripts of abject subjects. Public health discourse was alive to the threat of culturally strange ne'er-do-wells and the melting pot of undesirability that included not just criminals and disabled migrants but also people of colour (Snyder and Mitchell 2006: Dolmage 2014). The cast of degeneracy conflated 'feeblemindedness' - a term invented in Ellis Island - with stereotypes of minority ethnic retardation. Eugenics massaged the myth of an intersectional threat to the health and purity of the population: 'non-white races were routinely connected to people with disabilities, both of whom were depicted as evolutionary laggards or throwbacks' (Baynton 2001: 36). These groups - conflated beyond recognition into an undifferentiated identity of degeneracy - were consigned to the moral margins, helping, simultaneously to sketch out both the vice of peripheral lives and the virtues of the normate core of citizenship and nationhood (Galusca 2009). Though often associated singularly with the irrationality of Nazism, eugenics was not only attractive to 'racists and extremists' but was, 'an implicit part of Western cultural assumptions' (Marks 1999: 35). The movement attracted a widespread constituency and was deeply embedded in the scientific orthodoxy of the major Atlantic rim countries where it became a 'transnational ideology' (Snyder and Mitchell 2006: 112-21) and a legitimate means of pointing the finger at the legions of 'social detritus' that impaired the route to a 'better' society and undermined the promise of progress. Cleansed of the sources of moral degeneracy, society would be 
able to migrate towards a better tomorrow. Controlling 'disability on the move' was a central part of this transnational agenda of which Ellis Island was a part.

A similar logic of ableism and exclusion was applied to migrations internal to the US - to, for example - the mass movement of people from the countryside to the growing industrial cities. Section 36034 of the Chicago Municipal Code - still in place until after the Second-World-War - read: 'Any person who is diseased, maimed, mutilated or in any way deformed so as to be an unsightly or disgusting objects, or an improper person to be allowed in or on the streets, highways, thoroughfares or public spaces in this city, shall not therein or thereon expose himself to public view under the penalty of a fine of \$1 for each offense' (Quoted in Schweik 2009: 1-2). Disability segregation was central to the 'Ugly Laws': Laws that single out the same kind of 'improper' persons that were returned from Ellis Island to their homelands. They were 'improper' by virtue of being maimed or diseased or mutilated, 'down-atheal' beggars or putative criminals. It was assumed that they would constitute an economic cost. As Ellis Island officials put it, when invoking one of their categories for excluding candidates from entry, they were 'likely to become a public charge' (Bateman-House and Fairchild 2008: 236). The same category was invoked, in the twentieth century at the Mexican border to refuse entry to Latino migrants (Molina 2014: 91-1). Both disability and ethnicity were assumed to be potentially idle and burdensome and, therefore, not fit to contribute to American society.

The idea that disabled people constituted a potential contaminant to the body politic is a theme that declined in importance when the Nazis gave eugenics a bad name in the middle of the $20^{\text {th }}$ century. Yet the importance of the racist/ableist doctrine of eugenics in the formation of ideals of US citizenship is central to the story of the policing of American immigration as well as its urban public spaces. The American dream is a dream of success and social mobility but it is also based on an 'imaginary nation' of white, able bodied, citizens. The story of the policing and expulsion of disability at Ellis Island provides a case study of citizenship shaped by the intersection of discriminatory fantasies (Galusca 2009)

\section{Neo-liberalism and parasite identities}


In the neoliberal era, anxiety in relation to the incomer draws on the bank of negative, intersecting scripts that history has lodged in the archive of disability invalidation. The moral majority, in the heartlands of neo-liberalism, has come to resent, above all else, those suspected of making little or no contribution to the commonwealth. Anti- migration populism (McTernan 2011), including the welfare chauvinism that accompanies it and the despoilment of the deserving status of the disabled claimant, can be located in the same frame of reference. As one commentator noted: 'The illegal immigrant, the benefit scrounger and the criminal are not just parallels ... they are intrinsically related both to each other and their shadows, the migrant and the claimant' (Anderson 2015:7). The fear that follows these shadows prevails in the normative imaginary in the form of 'bogus' racialized refugees and disabled 'counterfeit citizens' (Hughes 2015). Both representations of identity embody deception.

One of the tensions in the experience of social flux associated with the mass migrations of the neoliberal era is the debate around access to welfare benefits and services: 'The growing presence of newcomers ... is ' some argue, ' eroding the sense of social solidarity on which welfare states are constructed' (Johnston et al 2010: 351). In this context, the relationship of asylum seekers and refugees to welfare is represented, as parasitic (Philo et al 2013). The echo of Ellis Island - of the likelihood of a 'public charge' - is palpable. Embedded in the popular imaginary in the UK is the view that the 'generous' welfare system is the reason that the country is attractive to those seeking a life of hand-outs and state funded relaxation. The portrayal of the British Welfare State as a nirvana of ease for the comfort of global waifs and strays - what Philo et al (2013: 35-39) call 'soft touch Britain' validates benefit cuts for disabled people who have been 'tarred with the same brush' as 'alien scroungers'. Punishment for the poor masquerades under the populist, neoliberal euphemism of 'welfare reform'. Access to welfare benefits and services for 'incomers' and disabled locals has been subjected to progressive (sic) restriction with both parties conflated in common scripts of undesirability in which they are represented as idle by lifestyle choice. In Boswell's view (2003) it has become the convention, not just in Britain but throughout Europe, to interpret the immigrant as a burden who comes uninvited, to drain resources by, either seeking an idle life on benefits or through making demands on housing, education and 
assistance which local communities can ill afford. As well as home-grown layabouts, there are 'hordes' of 'alien' beggars, we hear, waiting at the border.

Neoliberal Britain has made significant headway in dismantling the 'safety net' of welfare support that once helped to protect disabled people from the discrimination and exclusion built into the social fabric. One calculation suggests that from 20102012 'disabled people and their carer's have seen their income collectively cut by $£ 500$ million' (Butler 2012). Changes to 13 Benefits, available to disabled people prior to the welfare 'reforms' of 2011 , will result, by 2018, in a loss of income of $£ 28.3$ billion for the 3.7 million disabled people that live in the United Kingdom (Demos 2013). The use of insidious representation of disabled people as benefit cheats and mendicants without begging bowls has been widely deployed to discredit disabled claimants (Briant et al 2013) and to legitimate the swingeing cuts. A normative reconstruction of disability is a priority for the neoliberal state. Repertoires of invalidation undermining the 'deserving' status of those who make claims on the public purse have been mobilised. The privatisation and deregulation of the ethics and politics of care is largely dependent on discrediting the character of disabled people; a task for which there is many historical examples, for advocates of neoliberal policies, to draw upon (Hughes 2015). The beggar, we hear, is in the corridors of the exchequer.

Without proof of means to look after ones-self, there is - to gloss Georg Simmel's beautiful essay - no welcome at the door, no bridge to take one to one's destination of desire. Those seeking hospitality - be they internal or external to the increasingly bounded, 'imagined' 'community of value' (Anderson 2015) - meet with refusal and disparagement. The new border is one of 'virtuous citizenship' and neither migrants nor disabled people carry the right passports to enter the pristine territory beyond. Folk devils congregate outside the virtuous circle of citizenship, looking for opportunities to break through the walls and disturb its decency. The moral calculi that keeps 'them' out focuses on the 'crookedness' of disability (Briant et al 2013; Garthwaite 2011) and the criminality of the incomer (See for example Banks 2008; Webber 2008). Meanwhile, the 'virtuous citizen' feels the economic pain; growing resentful at having to dig deep into threadbare pockets to save foreigners from destitution and to subsidise the idleness of disabled benefit fraudsters. The moral 
calculus that kept migrating disabled bodies on the wrong side of the pearly gates is, in the Ellis Island and contemporary UK examples, repositioned as, primarily, a matter of economic parsimony. Yet the same scripts of moral degeneracy - applied at the intersection between disabled people and incoming foreigners - are used to legitimate the tightening of the purse strings to the 'crippling' material disadvantage of those least able to afford it.

Michael Keith (2013: 27), calls the contemporary 'campaign' of nefarious representation against, and criminalisation of, asylum seekers and refugees a manifestation of the 'bigot's' calculus at the cost of arrivals'. He strips back the antiimmigrant narrative to its locus in greed. On a parallel note one might speak of the 'miser's calculus'; the cost that 'virtuous citizens' feel that they pay for 'bogus incapacity'; for people 'pretending to be disabled', 'swinging-the-lead', playing-up their impairments in order to dupe the custodians of the public purse into doling out billions to counterfeit claims for disability benefits.

The bigot's calculus epitomises the neoliberal mind-set. It equates, not to the hard currency costs of 'looking after immigrants' - a complaint that has never been translated into a believable bottom line - but to the wrath, invective and hostility that it musters in press and population (Leudar et al 2008). Likewise, the miser's calculus, mobilised by those who like to 'bash' disabled benefits claimants, is measured out in accusations of laziness and fraudulent conduct (Briant et al 2013; Garthwaite 2011). These repertoires of invalidation, focused on the so-called abuse of the welfare system by the marginalised and disadvantaged, are strikingly commensurate, with the lynchpins of neoliberal economics and social politics which has brought about the 'triumph of the market over citizenship '(Crouch, Eder and Tambini 2001: 11) and the 'the silent surrender of public responsibility' (Gilbert 2004). Both the triumph and the surrender ensure that a politics of hospitality and care is de-legitimated. The neoliberal hegemony is working hard to ensure that social need is individualised, the moral economy privatised and national borders water-tight. 'Brexit' - a political phenomenon that has invested heavily in cultural racism and ableism - is its latest manifestation. 
The migrant as foreign welfare burden is a theme that replays the emotional and economic sentiments that shape the contemporary disability/non-disability relationship. It is a key test of tolerance and a quandary around which the social relations of hospitality and care are stretched. The growth of intolerance to mass migration and multiculturalism in the UK and more widely in Europe and the Global North is aligned - fittingly for neoliberals - with intolerance for home grown 'dependency'. The ranks of the deserving are redefined by administrative fiat. The shutters at the borders are battened down. The 'scroungers within' have new allies in idleness who are at the gates and keen to swell their ranks.

Neo-liberalism closes down the social state to the detriment of disabled people. Simultaneously, it re-imagines migration in terms of productivist priorities to the detriment of people trapped in situations of violence and persecution. Both disabled people and immigrants are subjected to similar 'scripts' or repertoires of invalidation; to the same sneering language of abjection.. 'They' are the ubiquitous other. They take but do not give. The UK provides a case study of a society witnessing not only the collapse of hospitality and compassion but worse; the stigmatisation of those very people - non-white, disabled, impoverished - who are the exemplary products of 'negative globalisation' and the injustice it generates (Bauman 2007). The demonization of disabled people and of ethnic immigrants, who make any kind of claim on the community, has become a commonplace. They are portrayed (interchangeably) as stalwarts of contemporary mendicancy; part of the abject underclass of contemporary neoliberalism (Tyler 2013).

\section{Conclusion}

Ableist hegemony (Campbell 2009) defines disability as negative embodiment; as a state of social existential invalidity. The migration of 'negative embodiment' into spaces inhabited by the non-disabled, invulnerable self is a source of dread.

Estranged by the modern courtesans of perfection - medicine, genetics, consumption, the fashionable aesthetics of embodiment - the contemporary self has found new ways of distancing itself from the frailties of human being. Fear of the inevitable, of the human journey towards decline and death and the fantastically exaggerated 'spectre' of impairment and disability that accompanies it, prompts the 
modern character to prefer the indulgences of the gratifying present to the reflexive consideration of the manifest obdurateness of nature (Shildrick 2002: Bauman 2007). The three historical vignettes that have been developed in this paper illustrate that, in the non-disabled imaginary, past and present is a heavily policed ontological border - a high wall - over which able-bodied participants are afraid to look.

The disavowal of impairment and disability stunts human being and becoming. It consigns difference to the margins and condemns non-disability to a disturbingly naive fantasy of well-being in which nefarious, intersectional figures are invented to shore up the conviction that the moral degeneracy can mutate at will. Racism and ableism have been partnered by dominant, normate interests in all three of the historical moments that have been examined in this paper. The shape taken by scripts of social disreputability shift over time. They do so, however, by borrowing from a relatively stable pool of repertoires of nefariousness and abjection. There is, or was, no place for impairment in heaven; nor in the USA. Purification and deportation are the respective policy responses to the potential infiltration of degeneracy. An economic calculus for the rejection of disabled migrants underpins both 'modern' case studies'. Neoliberalism, however, distinguishes itself by reconfiguring the parameters of desert. Disability fails the test; loses its deserving status because it has become a threat to the fiscal security of 'normal' people, many of whom seem to have internalised the message that disability is a lifestyle choice (Scope 2011). Appeals to the racialized notion of the lazy foreigner - standard fare of British (post)colonialism - provide a ready stereotype, through which the common, disreputable 'nature' of the disabled other is portrayed. It seems clear that migrating 'individuals located perilously at the interstices of race ... and disability are constituted as non-citizens and no-bodies' (Erevelles and Minear 2010:127) by ableist authorities and institutions who fear the arrival of difference.

With respect to the disabled migrant, there is also an existential calculus to consider which draws, too, for its concrete contents on the accretions of the past. If disability signifies loss of bodily control, more precisely the fear of it, as Susan Wendell (1996) has argued; then the immigrant is constructed as a threat to the social body and to social identity (Innes 2010). Both 'invade' beloved territories: the first the territory of the flesh; the second the territory of place or home. It is on these existential grounds 
that discrimination against immigrants and disabled people prosper and it is on these grounds that the border guards of 'normate' communities seek to assail the racialized reputation of the 'invaders'.

When we commune with others whose displacement and vulnerability are, at the moment of our meeting, tantamount to their identity we must be able to recognise these features of who they are as our own: If we look closely enough and see through the opaque calculus of prejudice and bigotry, we will, inevitably, see ourselves. How to make our vision for the future correspond to the image in the mirror of hospitable self-recognition is the most compelling concern of the age.

\section{References}

ANDERSON, B. (2015) Us and Them: The Dangerous Politics of Immigration Control, Oxford: Oxford University Press

AMIN, A. (2012) Land of Strangers, Oxford: Polity Press

BANKS, J. (2008) The Criminalisation of Asylum Seekers and Asylum Policy, Prison Service Journal, 75: 43-9

BATEMAN-HOUSE, A., and FAIRCHILD, A. (2008) Medical examination of immigrants at Ellis Island, American Medical Association Journal of Ethics, 10 (4): $235-41$

BAUMAN, Z. (1997) Postmodernity and its Discontents (Cambridge, Polity)

BAUMAN, Z. (1998) Globalization - The Human Consequences, Cambridge: Polity Press

BAUMAN, Z. (2007) Liquid Fear, London: Palgrave 
BAYNTON, D. (2001) Disability and the justification of inequality in American history, pp. 33-57, in P. Longmore and L. Umansky, (Eds.) The New Disability History, New York: New York University Press

BECKETT, A. (2006) Citizenship and Vulnerability, Basingstoke: Palgrave Macmillan

BRIANT, E., WATSON, N., and PHILO, G. (2013) Reporting disability in the age of austerity: The changing face of media representation of disability and disabled people in the United Kingdom and the creation of a new 'folk devil', Disability \& Society, 28 (6): 874-889

BROCK, B. (2012) Augustine's hierarchy of human wholeness and their healing, pp. 65-100 in B Brock and J Swinton (Eds.) Disability in the Christian Tradition, W.B. Eerdmans Publishing Company: Cambridge

BOSWELL, C. (2003) Burden sharing in the European Union: lessons from the German and UK experience, Journal of Refugee Studies, 16 (3): 316-33

BUTLER, P (2012) Disabled people hit especially hard by cuts, finds report, Guardian, June 22, 2012: Retrieved from http://www.guardian.co.uk/society/2012/jun/22/disabled-people-hit-hard-cuts

CAMPBELL, F.A.K. (2009) Contours of ableism: The production of disability and abledness, Basingstoke: Palgrave Macmillan.

CASTLES, S., and MILLER, M. (2003) The Age of Migration: International population movements in the modern world, ( $3^{\text {rd }}$ Edition), New York: The Guilford Press

CISNEROS, D. (2008) Contaminated communities: The metaphor of 'immigrant as pollutant' in media representations of immigration, Rhetoric and Public Affairs, 11 (4): 569-601 
COULDRY, M. and HERSON, M. (2010) Editorial in M. Couldrey and M. Herson (Eds.) Disability and Displacement, Forced Migration Review, Issue 35, July

CROUCH, C., EDER, K., and TAMBINI, D. (Eds.) (2001) Citizenship, Markets and the State, Oxford: Oxford University Press

CUSACK, C. (1997) Graciosi: medieval Christian attitudes to disability, Disability and Rehabilitation, 19 (10): 414-419

DEMOS (2013) Disabled People Set to lose $£ 28.3$ Billion of Support, http://www.demos.co.uk/press release/destinationunknownaplil2013 (accessed 17.1.14)

DOLMAGE, J. (2011) Disabled upon arrival: The rhetorical construction of disability and race at Elis Island, Cultural Critique, 77: 24-69

DOLMAGE, J. (2014) Framing disability, developing race: Photography as Eugenic Technology http://www.enculturation.net/framingdisability (accessed 3/5/2016)

DOUGLAS, M. (1970) Purity and Danger: An Analysis of the Concepts of Pollution and Taboo, Harmondsworth: Penguin

EREVELLES, N., and MINEAR, A. (2012) Unspeakable offenses: Untangling race and disability in discourses of intersectionality, Journal of Literary and Cultural Disability Studies, 4 (2): 127-46

FAIRCHILD, A. (2003) Science at the Borders: Immigrant medical inspection and the shaping of the modern industrial labour force, Baltimore: John Hopkins University Press

FOUCAULT, M. (1979) The History of Sexuality: Volume 1: An Introduction, London: Allan Lane 
GALUSCA, R. (2009) From fictive ability to national identity: Disability, medical Inspection and public health regulations on Ellis Island, Cultural Critique, 72: 137-63

GARTHWAITE, K. (2011) The language of shirkers and scroungers? Talking about illness, disability and coalition welfare reform, Disability \& Society, 26(3): 369-72

GAVENTA, J. and TANDON, R. (2010) Globalizing Citizens: New Dynamics of Inclusion and Exclusion, New York: Zed Books

GILBERT, N. (2004) Transformation of the Welfare State: The Silent Surrender of Public Responsibility, Oxford: Oxford University Press

GOGGIN, G. and NEWALL, C. (2005) Disability in Australia: Exposing a Social Apartheid, Sydney: University of New South Wales Press

HARRIS, J. (2003) 'All doors are closed to us': a social model analysis of the experience of disabled refugees and asylum seekers in Britain, Disability \& Society, 18 (4): $395-410$

HUGHES, B. (2002) Bauman's Strangers: Impairment and the Invalidation of Disabled People in Modern and Postmodern Cultures, Disability and Society, 17 (5): $571-584$

HUGHES, B. (2012) Fear, pity and disgust: emotions and the non-disabled imaginary, pp. 68-78, in N. Watson, A. Roulstone and C. Thomas (Eds.) Routledge Handbook of Disability Studies, London: Routledge

HUGHES, B. (2015) Disabled people as counterfeit citizens: the politics of resentment past and present, Disability \&Society, 30, (7): 991-1004

INNES, A. (2010) When the threatened become the threat: The construction of asylum seekers in British media narratives. International Relations 24, no. 4: 456477 
JOPPKE, C. (2010) Citizenship and Immigration, Cambridge: Polity Press.

JOHNSTON, R., BANTING, K., KYMLICKA, W., and SOROKA, S. (2010) National Identity and support for the welfare state, Canadian Journal of Political Science, 43 (2): $349-377$

KEITH, M. (2013) Beyond European imaginaries: The paradoxical cartography of a land of strangers, Identities: Global Studies in Culture and Power, 20 (1): 24-30

LEUDAR, I., HAYES, J., NEKVAPIL, J., and TURNER BAKER, J. (2008) Hostility themes in media and refugee narratives, Discourse and Society, 19(2):187-221

McLAUGHLIN, A (1905) How immigrants are inspected at Ellis Island circa 1903, The Popular Science Monthly, 66: 357-361 http://www.gjenvick.com//mmigration/Ellis Island/1905-02-HowlmmgrantsArelnspected/index.html (Accessed 19/05/2016)

McTERNAN, M (Ed.) (2011) Exploring the Cultural Challenges to Social Democracy: Anti-immigration populism, identity and community in an age of insecurity, London: Policy Network

MARFLEET, P. (2006) Refugees in a Global Era, Basingstoke: Palgrave Macmillan MARKS, D. (1999) Disability: Controversial debates and Psychosocial Perspectives, London: Routledge

METZLER, I (2006) Disability in Medieval Europe: Thinking about Physical Impairment During the High Middle Ages, c.1100-1400, Routledge: London

MOLINA, N. (2014) How Race is made in America: Immigration, Citizenship and the Historical Power of Racial Scripts, Berkeley: University of California Press

MOLINA, N. (2006) Medicalizing the Mexican: Immigration, Race and Disability in the Early Twentieth Century United States, Radical History Review, 94, Winter: 12745 
MOORE, R. (1987) The Formation of a Persecuting Society, Oxford: Basil Blackwell

PENDER, S. (1996) No monsters at the resurrection: inside some conjoined twins, in J. Cohen (Ed.) Monster Theory, Minneapolis, Minnesota University Press

PHILO, G., BRIANT, E., and DONALD, P. (2013) Bad News for Refugees, London: Pluto Press

PORTER, R. (2003) Flesh in the Age of Reason, Harmondsworth: Penguin

PICK, D. (1989) Faces of Degeneration: European Disorder 1848-1918, Cambridge: Cambridge University Press

QUAYSON, A (2007) Aesthetic Nervousness: disability and the crisis of representation, New York, Columbia University Press

ROSE, N. (2001) The politics of life itself, Theory, Culture \& Society: 18 (6): 1-30

SAID, E. (2003) Orientalism, London: Penguin Books

SCOPE. 2011. Deteriorating attitudes towards disabled people.

www.scope.org.uk/news/attitudes-towards-disabled-people-survey (16.1.2014)

SCHWEIK, S. (2009) The Ugly Laws, New York: New York University Press

SHAKESPEARE, T. (1994) Cultural representation of disabled people: Dustbins of disavowal, Disability \& Society 12 (2): 293-300

SHILDRICK, M. 2002. Embodying the Monster: Encounters with the vulnerable self. London: Sage.

SIEBERS, T. (2008) Disability Theory, Ann Arbor: University of Michigan Press 
SIMMEL, G. (1971) The stranger, in: D. Levine (Ed.) Georg Simmel on Individuality and Social Forms, Chicago, IL: University of Chicago Press

SNYDER, S. and MITCHELL, D. (2006) Cultural locations of Disability, Chicago and London: The University of Chicago Press

SOLDATIC, K., and MEEKOSHA, H. (2012) The place of disgust: Disability, class and gender in spaces of workfare, Societies, 2 (4): 139-56

STAINTON, T. (2008) Reason, grace and charity: Augustine and the impact of church doctrine on the construction of intellectual disability, Disability \& Society, 23 (5): 485-496

STIKER, H.J. (1999) A History of Disability, Translated by W Sayers, Ann Arbor: University of Michigan Press

SWAIN, J., FRENCH, S., BARNES, C., and THOMAS, C. (2014) Disabling Barriers Enabling Environments, London: Sage

TYLER, I. (2013) Revolting Subjects, London: Zed Books

WEBBER, F. (2008) Border Wars and Asylum Crimes, London: Statewatch

UNHCR (2017) Figures at a Glance, http://www.unhcr.org/figures-at-a-glance.html (Accessed 18/1/2017)

WENDELL, S. (1996) The Rejected Body, London: Routledge

WHEATLEY, E. (2010) Stumbling Blocks before the Blind: Medieval Constructions of a Disability, Ann Arbor, University of Michigan Press 
